\title{
PRAKIRAAN CURAH HUJAN KECAMATAN KAIRATU KABUPATEN SERAM BAGIAN BARAT DENGAN MODEL AUTOREGRESIVE INTEGRATED MOVING AVERAGE (ARIMA)
}

\author{
GRACE LOUPATTY \\ Jurusan Fisika, FMIPA,UNPATTI
}

\begin{abstract}
Forecasting is an activity to use the past data as the basic to predict the future event that will occur. The result from the prediction is an un-sure event or just a guess, but with some certain methods then the prediction will be more than a guess, it means that it is a scientific guess. The data analysis technique with autoregressive integrated moving average (ARIMA) method can give the early information that is needed as the material for the consideration to take the decision and the action itself.
\end{abstract}

\section{Keywords: Forecasting, time series data, stationerity, Mean Squared Error (MSE), Mean Absolute Error (MAE).}

\section{PENDAHULUAN}

Curah hujan adalah endapan atau deposit air dalam bentuk cair maupun padat yang berasal dari atmosfer. Curah hujan mencakup tetes hujan, salju, batu es, embun, dan embun kristal. Embun kristal adalah kristal-kristal es yang terbentuk pada permukaan, misalnya pada tanaman yang disebabkan oleh rendahnya suhu. Informasi tentang banyaknya curah hujan adalah salah satu unsur penting dan besar pengaruhnya terhadap segala macam aktifitas kehidupan seperti: keselamatan masyarakat, produksi pertanian, perkebunan, perikanan, penerbangan, public service, dan sebagainya. Prakiraan curah hujan dengan segala bentuk analisis dan informasi yang dihasilkan besar dampaknya guna membantu dan menunjang kegiatan sosial ekonomi di Indonesia. Hasil prakiraan curah hujan dapat dilihat pada beberapa media. Namun, masih banyak yang belum tahu bagaimana memprakirakan curah hujan itu.

Pada penelitian ini penulis mengambil tempat penelitian di daerah Kecamatan Kairatu dengan alasan Kecamatan Kairatu merupakan daerah yang memiliki curah hujan yang cukup tinggi karena selain intensitas terjadinya hujan yang cukup tinggi. Perkembangan statistik sebagai metode ilmiah telah mempengaruhi tiap aspek kehidupan manusia. Salah satunya adalah prakiraan curah hujan. Stasiun Meteorologi Pattimura Ambon adalah unit pelaksanaan teknis yang mempunyai tugas menyelenggarakan prakiraan curah hujan di setiap daerah di wilayah Maluku termasuk di daerah Kairatu. Peranan metode statistik dalam prakiraan curah hujan dalam kurun waktu sekarang semakin besar. Peramalan merupakan cabang ilmu statistik yang merupakan salah satu unsur penting dalam pengambilan keputusan.

Terdapat sejumlah fenomena besar yang saat ini hasilnya diramalkan secara mudah. Kemajuan ilmu pengetahuan dan teknologi telah meningkatkan pengertian mengenai berbagai aspek lingkungan dan akibatnya banyak peristiwa yang dapat diramalkan. Ramalan yang dilakukan umumnya berdasarkan pada data masa lampau yang dianalisis dengan menggunakan cara-cara tertentu. Data masa lampau dikumpulkan, dipelajari, dan dianalisis dihubungkan dengan gerakan waktu. Karena adanya faktor waktu ini, maka hasil analisis tersebut kita mencoba menyatakan sesuatu yang akan terjadi di masa yang akan datang jelas dalam hal ini kita berharap ke tidakpastian sehingga akan ada faktor ke seksamaan yang harus diperhitungkan. Yang jelas tidak akan selalu didapatkan hasil ramalan dengan ketepatan 100 \%.Ini tidak berarti ramalan menjadi percuma. Sebaliknya terbukti bahwa ramalan telah banyak digunakan dan membantu dengan baik dalam berbagai manajemen sebagai dasar-dasar perencanaan, pengawasan, dan pengambilan keputusan. Salah satunya adalah peramalan curah hujan atau dalam dunia klimatologi biasa disebut dengan prakiraan curah hujan. Untuk keperluan analisis peramalan, ada tiga model yaitu : model ekonometrika, model deret berkala, dan model ramalan kualitatif. Model peramalan ARIMA merupakan salah satu model ramalan deret berkala yang bertujuan untuk mencari pola data yang paling cocok dari sekelompok data.

\section{TINJAUAN PUSTAKA}

Angin yang mengandung uap air dan naik ke atas karena suhu yang makin rendah kemudian mengembun dan berkumpul. Kumpulan embun tersebut membentuk awan. Kumpulan embun ini bergabung menjadi titik-titik air dan kemudian jatuh ke tanah. Jatuhnya titik-titik air ini disebut hujan (Arismunandar, 1988).

Yang dimaksud dengan curah hujan adalah endapan atau deposit air dalam bentuk cair maupun padat yang berasal atmosfer. Hal ini berarti curahan mencakup tetes hujan, salju, batu es, embun, dan embun kristal. Embun kristal adalah kristal-kristal es yang terbentuk pada permukaan, misalnya pada tanaman yang disebabkan oleh rendahnya suhu, yaitu lebih rendah dari $0^{\circ} \mathrm{C}$. Oleh karena itu banyaknya curah hujan dinyatakan dengan satuan milimeter (mm).(Susilo Prawirowardoyo, 1996).

Dalam perkembangan bidang pendugaan (prediction) dan penaksiran (estimation) yang mempunyai kaitan dan dapat digunakan secara langsung dalam peramalan, mengalami kemajuan 
dalam hal teori dan praktek. Literatur peramalan sekarang baru menitikberatkan pada penerjemahan apa yang secara teoritis memungkinkan dan secara perhitungan layak kedalam bentuk yang dengan mudah dapat dimengerti dan diterapkan. Aplikasi metodologi peramalan yang baik didapat dengan mengenal semua teknik yang ada dengan karakteristiknya dan pemilihan metode yang tepat dan mempergunakannya dengan sukses dalam situasi tertentu.

Pada awalnya model peramalan didomonasi oleh model persamaan simultan, namun demikian sejak tahun 1973 dan 1979 penggunaan model persamaan simultan untuk peramalan mulai ditinggalkan, faktor lain adalah adanya kritik dari Lucas (1976) yang menyatakan bahwa estimasi parameter dari model ekonometrik tergantung dari kebijakan yang terjadi pada saat model peramalan diestimasi dan akan berubah jika ada perubahan kebijakan. Publikasi artikel dengan judul Time Series Analysis : Forecasting and Control yang dilakukan oleh Box dan Jenkins mengisyaratkan munculnya alat peramalan generasi baru. Teknik ini dikenal dengan nama Metodologi Box-Jenkins (BJ), tetapi secara teknik disebut Metodologi ARIMA (Autoregressive Integrated Moving average). Penekanan metode ini bukan membangun suatu persamaan tunggal atau persamaan simultan, tetapi menganalisis probabilitas atau sifat random (stochastic) dari suatu data time series itu sendiri atau secara filosofi let the data speak themeselves. Tidak halnya pada model regresi dimana $Y t$ dijelaskan oleh $\mathrm{i}$ regrusor $X_{1} X_{2} X_{3} \ldots X_{i}$ tetapi model BJ merupakan model time series dimana $Y t$ dijelaskan (diregres) oleh nilai masa lalu atau lagged, dari nilai $Y$ itu sendiri dan stochastic error term (residual). Oleh karena itu model ARIMA sering disebut model tanpa teori (a-theoritc model) karena model ini tidak diturunkan dari teori ekonomi(Imam Ghozali,2006).

Model AR pertama kali diperkenalkan oleh Yule (1926) dan kemudian dikembangkan oleh Walker (1931). MA pertama kali digunakan oleh Sluzky (1937), akan tetapi Wold (1938) yang menghasilkan dasar-dasar teoritis. ARIMA dikatakan sebagi model yang komplek karena selain merupakan gabungan antara AR dan MA, model peramalan ini tidak mensyaratkan suatu pola data tertentu supaya model dapat bekerja dengan baik, dengan kata lain metode ARIMA dapat dipakai untuk semua tipe pola data.

Sejalan dengan perkembangan teori peramalan dan ilmu statistik, metode ARIMA merupakan metode yang secara intensif dikembangkan oleh George Box dan Gwilym Jenkins (1976) sehingga nama mereka sering disinonimkan dengan proses ARIMA yang diterapkan untuk analisis dan peramalan data time series. Teknik analisis data dengan metode ARIMA dilakukan karena merupakan teknik untuk mencari pola yang paling cocok dari sekelompok data (curve fitting), dengan demikian ARIMA memanfaatkan sepenuhnya data masa lalu dan sekarang untuk melakukan peramalan jangka pendek yang akurat (Sugiarto dan Harijono, 2000).

\section{Curah Hujan}

Pengertian curah hujan $1 \mathrm{~mm}$ adalah air hujan yang jatuh pada permukaan datar seluas 1 meter persegi (m2) setinggi $1 \mathrm{~mm}$ dengan tidak meresap, mengalir ataupun menguap. Curah hujan diukur dengan menggunakan alat yang disebut penakar hujan. Ada dua macam penakar hujan yaitu penakar hujan non rekam dan penakar hujan rekam.

\section{Prakiraan Curah Hujan}

Saat ini metode prakiraan curah hujan bulanan dan musiman yang di lakukan oleh Badan Meteorologi dan Geofisika (BMG) dapat dibagi menjadi 2 yaitu:

\section{a. Metode Yang Berbasis Statistik}

Metode yang berbasis statistik umumnya bersifat objektif dalam arti hasil keluaran (output) murni dari perhitungan formula yang digunakan. Ada beberapa cara yang digunakan dalam menggunakan metode statistik yaitu:
1. Regresi Linier
2. Regresi Linier Ganda
3. Model Probabilitas
4. Model ARIMA

\section{b. Metode Fisis atau Dinamis}

Metode fisis atau dinamis adalah melihat perkembangan parameter-parameter cuaca baik secara mingguan maupun bulanan. Untuk mengikuti perkembangan parameter ini digunakan data-data dari internet yang dapat diakses setiap saat. Parameter ini sangat berguna untuk mengetahui perkembangan cuaca dalam skala regional maupun global, terutama untuk memonitor sekaligus memprediksi gejala-gejala cuaca ekstrim. Metode yang digunakan adalah analogi-analogi serta analisisnya, karena hubungan antara teori dan penelitian seperti siklus sehingga metode dinamis bersifat subjektif. Namun demikian metode ini sangat berguna untuk membuat koreksikoreksi dari hasil perhitungan metode secara statistik.

\section{Peramalan \\ a. Definisi dan Tujuan Peramalan}

Pada dasarnya definisi ramalan menurut istilah adalah hasil meramal. Meramal mengandung pengertian menduga sesuatu yang akan terjadi. Jadi peramalan adalah proses menduga sesuatu yang akan terjadi di masa yang akan datang. Menurut teori peramalan (forecasting) adalah perkiraan mengenai sesuatu yang belum terjadi. Peramalan bertujuan mendapatkan ramalan yang bisa meminimumkan kesalahan meramal yang biasanya diukur dengan metode Mean Squared Error (MSE), Mean Absolut Error (MAE), dan sebagainya (Pangestu Subagyo, 1986).

\section{b. Hubungan Peramalan Dengan Rencana}

Ramalan adalah peramalan apa yang akan terjadi pada waktu yang akan datang melalui studi masa lalu, sedangkan rencana adalah penentuan apa yang akan dilakukan pada waktu yang akan datang. Peramalan pada umumnya digunakan untuk memprediksi sesuatu yang kemungkinan besar akan terjadi misalnya kondisi permintaan, banyaknya curah hujan, kondisi ekonomi, 
dan lain-lain. Sedangkan rencana menggunakan ramalanramalan yang ada untuk menetapkan target termasuk di dalamnya penetapan strategi untuk mencapai target itu. Dengan demikian peramalan ádalah perkiraan mengenai sesuatu yang belum terjadi. Sehingga dapat disimpulkan bahwa ramalan adalah peramalan yang akan terjadi, tetapi Belum tentu dapat dilaksanakan. Pengambilan keputusan mempengaruhi hasil akhir seperti yang diharapkan. Misalnya dari ramalan diramalkan curah hujan bulan Agustus 2007 sebesar $132 \mathrm{~mm}$. Maka belum tentu pada waktu tersebut banyaknya curah hujan sebesar itu. Namun setidaknya dengan adanya ramalan tersebut akan dapat dibuat rencana di berbagai bidang kehidupan manusia yang disesuaikan dengan kondisi banyaknya curah hujan tersebut.

\section{c. Prinsip Dalam Peramalan}

Metode peramalan dilakukan dengan cara mengekstrapolasi kondisi masa lalu untuk masa kondisi yang akan datang. Hal ini akan didasarkan pada asumsi bahwa kondisi masa lalu sama dengan kondisi masa mendatang. Atas dasar logika ini, langkah dalam metode peramalan secara umum adalah mengumpulkan data, menyeleksi dan memilih data, memilih model peramalan, menggunakan model terpilih untuk melakukan peramalan, evaluasi hasil akhir. Hal terpenting dalam peramalan ádalah dapat meminimumkan kesalahan peramalan.

\section{Analisis Runtun Waktu}

Analisis Runtun Waktu adalah suatu metode kuantitatif untuk menentukan pola data masa lalu yang telah dikumpulkan secara teratur. Analisis runtun waktu merupakan salah satu metode peramalan yang menjelaskan bahwa deretan observasi pada suatu variabel dipandang sebagai realisasi dari variabel random berdistribusi bersama. Gerakan musiman adalah gerakan rangkaian waktu yang sepanjang tahun pada bulan-bulan yang sama yang selalu menunjukkan pola yang identik, contohnya: musim hujan, musim panen. Gerakan random adalah gerakan naik turun waktu yang tidak dapat diduga sebelumnya dan terjadi secara acak contohnya: gempa bumi, kematian dan sebagainya. Data curah hujan adalah data runtun waktu yang berbentuk musiman, yakni cenderung mengulangi pola tingkah gerak dalam periode musiman, adanya korelasi beruntun yang kuat pada jarak semusim yaitu waktu yang berkaitan dengan banyak observasi per periode musim. Asumsi yang penting yang harus dipenuhi dalam memodelkan runtun waktu adalah asumsi kestasioneran artinya sifat-sifat yang mendasari proses tidak dipengaruhi oleh waktu atau proses dalam keseimbangan. Apabila asumsi stasioner belum dipenuhi maka deret belum dapat dimodelkan. Namun, deret yang nonstasioner dapat ditransformasikan menjadi deret yang stasioner. Runtun waktu adalah himpunan observasi berurut dalam waktu atau dimensi apa saja yang lain.

\section{Peramalan Dengan Metode ARIMA}

Metode ARIMA merupakan metode yang dikembangkan oleh George Box dan Gwilym Jenkins sehingga nama mereka sering disinonimkan dengan proses ARIMA yang diterapkan untuk analisis data dan peramalan data runtun waktu. Metode ARIMA berbeda dengan metode peramalan lain karena metode ini dapat dipakai untuk semua tipe pola data. Metode ARIMA akan bekerja dengan baik apabila data runtun waktu yang digunakan bersifat dependent atau berhubungan satu sama lain secara statistik. Secara umum model ARIMA dirumuskan dengan notasi ARIMA (p, d, q)

Dalam hal ini :

$\mathrm{p}=$ Orde atau derajat autokolerasi (AR)

$\mathrm{d}=$ Orde atau derajat pembeda

$\mathrm{q}=$ Orde atau derajat (MA)

Model ARIMA secara musiman umumnya dinotasikan :

ARIMA (p, q, d) (P, D, Q)s

Dalam hal ini : model

$$
(\mathrm{p}, \mathrm{d}, \mathrm{q})=\text { Bagian yang tidak musiman dari }
$$

$$
\begin{aligned}
(\mathrm{P}, \mathrm{D}, \mathrm{Q}) & =\text { Bagian musiman dari model } \\
\mathrm{S} & =\text { Jumlah periode musiman }
\end{aligned}
$$

\section{a. Model AR}

Model AR adalah model yang menggambarkan bahwa variabel dependent dipengaruhi oleh variabel dependent itu sendiri. Secara umum model AR mempunyai bentuk sebagai berikut:

$$
\begin{aligned}
& Y_{t}={ }_{\mathrm{f} 0+\mathrm{f} 1} Y_{t-1}+\cdots+\mathrm{f}^{p} Y_{t-p}+e_{t} \\
& \text { dimana : } \\
& Y_{t}=\text { nilai variabel dependent pada waktu } \mathrm{t} \\
& \mathrm{f}^{0} \quad=\text { intersep / nilai konstan }
\end{aligned}
$$

$Y_{t-p}=$ variabel dependent yang dalam hal ini merupakan lag (beda waktu) dari variabel dependent pada satu periode sebelumnya

$$
e_{t}=\text { residual pada waktu } \mathrm{t}
$$

Orde dari model AR diberi notasi p yang ditentukan oleh jumlah periode variabel dependent yang masuk dalam model.

\section{b. Model MA}

Secara umum model AR mempunyai bentuk sebagai berikut:

$$
\begin{gathered}
Y_{t}=\mathrm{W}_{0}+e_{t}-\mathrm{W}_{1} e_{t-1}-\mathrm{W}_{2} e_{t-2}-\cdots-\mathrm{W}_{q} e_{t-q} \\
\text { dimana : } Y_{t}=\text { nilai variabel dependent pada waktu } \mathrm{t} \\
\mathrm{W}_{0}=\text { intersep / nilai konstan } \\
e_{t-1}, e_{t-2}, \cdots, e_{t-q}=\text { nilai residual sebelumnya } \\
\mathrm{W}_{1}, \mathrm{~W}_{2}, \cdots, \mathrm{W}_{q}=\text { koefisien model MA yang }
\end{gathered}
$$
menunjukkan bobot

$$
e_{t}=\text { residual pada waktu } \mathrm{t}
$$

Perbedaan model MA dengan model AR terletak pada jenis variabel independent. Jika variabel pada model AR adalah nilai sebelumnya dari variabel independent maka pada model MA yang menjadi variabel independent adalah nilai residual pada periode sebelumnya. 


\section{c. Model ARIMA}

Model AR dan MA dikombinasikan untuk menghasilkan model ARIMA dengan bentuk umum sebagai berikut: $Y_{t}=\mathrm{f}_{0}+\mathrm{f}_{1} Y_{t-1}+\cdots+\mathrm{f}_{p} Y_{t-p}+\mathrm{W}_{1} e_{t-1}-$ $\mathrm{W}_{2} e_{t-2}-\cdots-\mathrm{W}_{q} e_{t-q}+e_{t}$

Dengan penggabungan ini diharapkan model ARIMA dapat mengakomodasi pola data yang tidak diidentifikasi secara sendiri-sendiri oleh model MA atau AR. Orde dari model ARIMA ditentukan oleh jumlah periode variabel independent baik dari nilai sebelumnya dari variabel independent maupun nilai residual periode sebelumnya. Untuk menyatakan model ARIMA (p,d,q) (P,D,Q)12 selanjutnya secara aljabar sederhana tetap dapat berkepanjangan. Di sini notasi yang sangat bermanfaat adalah operasi sift mundur (Backward) yang penggunaanya adalah $\mathrm{B} X_{t}=X_{t-1}$. Dua penerapan $\mathrm{B}$ untuk sift $X_{t}$ akan menggeser data tersebut dua periode ke belakang dan seterusnya. Dan notasinya adalah $\mathrm{B}\left(\mathrm{B} X_{t}\right)=B_{2} X_{t}=X_{t-2}$ untuk data bulanan maka digunakan $\mathrm{B}_{12}$ dan notasinya adalah $\mathrm{B}_{12} X_{t}=X_{t-2}$. Operasi sift mundur tersebut sangat tepat untuk proses pembedaan.

Pembedaan pertama:

$$
\begin{aligned}
& X_{t 1}=X_{t}-X_{t-1} \\
& X_{t 1}=\left(1-\text { B) } X_{t}\right.
\end{aligned}
$$

Misal dari model ARIMA $(0,1,1)(1,1,1)_{12}$

$$
\left(1-\mathrm{f}_{1} \mathrm{~B}_{12}\right)(1-\mathrm{B})\left(1-\mathrm{B}_{12}\right) \mathrm{Yt}=\left(1-\mathrm{W}_{1} \mathrm{~B}\right)\left(1-1 \mathrm{~B}_{12}\right) e_{t}
$$
dimana :

$$
\begin{aligned}
& \left(1-\mathrm{f}_{1} \mathrm{~B}_{12}\right)=\mathrm{AR}(1) \text { musiman } \\
& (1-\mathrm{B})=\text { pembedaan tidak musiman } \\
& \left(1-\mathrm{B}_{12}\right)=\text { pembedaan musiman } \\
& \left(1-\mathrm{W}_{1} \mathrm{~B}\right)=\text { MA (1) tidak musiman } \\
& \left(1-\mathrm{B}_{12}\right)=\text { MA (1) musiman }
\end{aligned}
$$

Jadi dalam penulisan model ARIMA musiman lebih efektif bila menggunakan operasi Backward agar notasi yang dipakai lebih sederhana. Secara lengkap langkahlangkah metode ARIMA adalah :

1. Kestasioneran data

2. Identifikasi model yang diselidiki

3. Estimasi parameter dalam model

4. Verifikasi model (diagnostik check)

5. Menggunakan model untuk peramalan.

\section{HASIL DAN PEMBAHASAN}

\section{Hasil Penelitian}

\section{Deskripsi data in-sample}

Data curah hujan tahun 1991-2002 disusun secara series yang mencakup sebanyak 144 data (Tabel 1) digunakan sebagai data periode pembentukan model.
Tabel 1. Data periode pembentukan model (in-sample)

\begin{tabular}{|c|c|c|c|c|c|c|c|c|c|c|c|c|}
\hline \multirow{2}{*}{ TAHUN } & \multicolumn{10}{|c|}{ BULAN } \\
\cline { 2 - 14 } & JAN & FEB & MAR & APR & MEI & JUN & JUL & AUG & SEP & OKT & NOP & DES \\
\hline 1991 & 163 & 141 & 63 & 107 & 170 & 111 & 168 & 111 & 73 & 138 & 18 & 56 \\
\hline 1992 & 47 & 47 & 117 & 143 & 120 & 98 & 256 & 243 & 135 & 42 & 20 & 179 \\
\hline 1993 & 28 & 48 & 108 & 97 & 145 & 69 & 413 & 60 & 87 & 109 & 66 & 52 \\
\hline 1994 & 150 & 42 & 61 & 173 & 138 & 70 & 136 & 19 & 72 & 15 & 215 & 43 \\
\hline 1995 & 175 & 127 & 212 & 183 & 339 & 111 & 33 & 116 & 135 & 127 & 121 & 95 \\
\hline 1996 & 236 & 34 & 88 & 54 & 228 & 264 & 349 & 245 & 246 & 124 & 125 & 140 \\
\hline 1997 & 138 & 64 & 64 & 214 & 204 & 290 & 179 & 327 & 161 & 203 & 50 & 186 \\
\hline 1998 & 95 & 230 & 204 & 160 & 79 & 32 & 257 & 305 & 102 & 111 & 58 & 62 \\
\hline 1999 & 29 & 76 & 58 & 188 & 241 & 702 & 279 & 557 & 225 & 220 & 60 & 150 \\
\hline 2000 & 84 & 92 & 142 & 147 & 325 & 303 & 399 & 328 & 328 & 396 & 64 & 252 \\
\hline 2001 & 114 & 92 & 136 & 88 & 172 & 584 & 383 & 323 & 180 & 159 & 50 & 175 \\
\hline 2002 & 156 & 192 & 211 & 145 & 400 & 519 & 189 & 70 & 187 & 133 & 223 & 113 \\
\hline
\end{tabular}

Tabel 2. Statistik Deskriptif data penelitian

\begin{tabular}{|l|c|}
\hline Mean & 163.33 \\
\hline Median & 138 \\
\hline Maximum & 702 \\
\hline Minimum & 15 \\
\hline Std. Deviasi & 118 \\
\hline
\end{tabular}

Statistik data in-sample (Tabel 1) menunjukkan rata-rata curah hujan selama 144 bulan sebanyak 163.33 mm, sedangkan nilai tengahnya $138 \mathrm{~mm}$. Nilai tertinggi dari deret waktu sepanjang 144 bulan adalah $702 \mathrm{~mm}$ sedangkan nilai terendah adalah $15 \mathrm{~mm}$. Nilai standar deviasi data sebesar $118 \mathrm{~mm}$ yang menggambarkan sebarang data disekitar data deret waktu .

\section{Deskripsi data out-sample}

Data untuk periode peramalan adalah data curah hujan tahun 2003-2009, dimana data tersebut digunakan sebagai penerapan dari model yang didapatkan.

Tabel 3. Data periode peramalan (out-sample)

\begin{tabular}{|c|c|c|c|c|c|c|c|c|c|c|c|c|}
\hline \multirow{2}{*}{ TAHUN } & \multicolumn{10}{|c|}{ BULAN } \\
\cline { 2 - 15 } & JAN & FEB & MAR & APR & MEI & JUN & JUL & AGST & SEP & OKT & NOP & DES \\
\hline 2003 & 173 & 43 & 171 & 109 & 222 & 98 & 10 & 60 & 80 & 14 & 117 & 94 \\
\hline 2004 & 120 & 146 & 105 & 234 & 128 & 97 & 516 & 69 & 114 & 70 & 28 & 98 \\
\hline 2005 & 57 & 139 & 73 & 127 & 241 & 143 & 68 & 26 & 56 & 64 & 43 & 74 \\
\hline 2006 & 86 & 48 & 364 & 188 & 103 & 267 & 508 & 82 & 87 & 303 & 108 & 229 \\
\hline 2007 & 147 & 209 & 77 & 707 & 147 & 944 & 174 & 32 & 105 & 5 & 77 & 91 \\
\hline 2008 & 53 & 153 & 79 & 171 & 160 & 631 & 109 & 156 & 326 & 222 & 74 & 232 \\
\hline 2009 & 153 & 128 & 133 & 121 & 128 & 13 & 50 & 52 & 30 & 69 & 42 & 230 \\
\hline
\end{tabular}

\section{Analisis Data}

Sebelum dilakukan pembentukan model dilakukan uji stasioneritas karena peramalan pada data time series mensyaratkan bahwa data yang ada bersifat stasioner. Jumlah diferensiasi data deret waktu akan menjadi nilai orde dalam model ARIMA yang digunakan.

\section{Uji Stasioneritas Data}

Data yang tidak stasioner memiliki rata-rata dan varian yang tidak konstan sepanjang waktu. Dengan kata lain, secara ekstrim data stasioner adalah data yang tidak mengalami kenaikan dan penurunan. Selanjutnya regresi yang menggunakan data yang tidak stasioner biasanya 
mengarah pada regresi lanjung. Untuk keperluan pengujian stasioner, akan dilakukan beberapa metode seperti metode grafik plot data dan correlogram. Correlogram merupakan peta / grafik dari nilai data, yang mana terdapat garis batas tingkat kepercayaan yang diwakili garis disisi atas sumbu (upper confidence limit) dan garis di bawah sumbu (lower confidence limit).

Secara sederhana dengan melihat Gambar 1 dapat dilihat bahwa terdapat kecenderungan naik dan turun pada data in-sample, yang mengandung implikasi bahwa pada periode pembentukan model bersifat non stasioner.

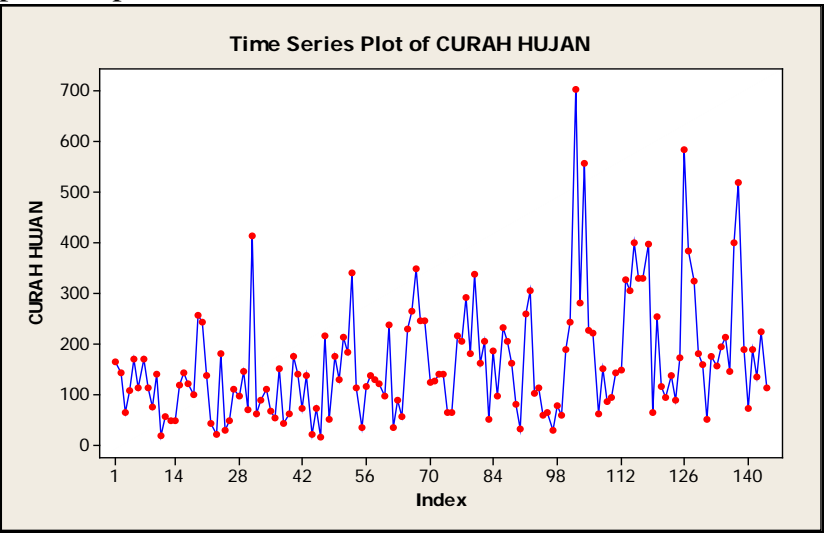

Gambar 1. Plot data curah hujan

Untuk mendukung pengamatan berdasarkan grafik, akan dilakukan uji correlogram. Pembentukan correlogram akan dimulai pada data asli dan berlanjut ke data hasil pembedaan (diffirencing). Apabila dilakukan perhitungan secara manual maka akan digunakan persamaan

$$
r_{k}=\frac{\sum_{t=1}^{n}\left(X_{t}-\bar{X}\right)\left(X_{t-1} \bar{X}\right)}{\sqrt{\sum_{t=1}^{n}\left(X_{t}-\bar{X}^{2}\right.} \sqrt{\sum_{t=2}^{n}\left(X_{t}-\bar{X}^{2}\right.}}
$$

Keterangan:

$$
\begin{aligned}
& r_{k}: \text { nilai ACF pada lag } \mathrm{k} \\
& x_{t}: \text { nilai deret berkala pada waktu } \mathrm{t} \\
& - \\
& x \text { : nilai tengah dari deret berkala }
\end{aligned}
$$

Hasil perhitungan ACF pada data in-sample dengan menggunakan SPSS terlihat pada Tabel 4 dimana disertakan perbandingan dengan T-statistik (t) dan LjungBox Statistic (LBQ).

Tabel 4. Nilai ACF data in-sample

\begin{tabular}{|c|c|c|r|}
\hline \multirow{2}{*}{ Lag } & ACF & \multicolumn{1}{|c|}{ T } & LBQ \\
\hline 1 & 0.386385 & 4.64 & 21.95 \\
\hline 2 & 0.328969 & 3.46 & 37.97 \\
\hline 3 & 0.030365 & 0.30 & 38.11 \\
\hline 4 & -0.004232 & -0.04 & 38.11 \\
\hline 5 & -0.162330 & -1.58 & 42.10 \\
\hline 6 & $-\odot .116312$ & -1.11 & 44.16 \\
\hline 7 & -0.155202 & -1.47 & 47.86 \\
\hline 8 & -0.017323 & $-\odot .16$ & $47.9 \odot$ \\
\hline 9 & $0.10570 \odot$ & 0.99 & 49.64 \\
\hline 10 & 0.268964 & 2.50 & $6 \odot .99$ \\
\hline 11 & 0.363563 & 3.24 & 81.89 \\
\hline
\end{tabular}

\begin{tabular}{|c|c|c|c|}
\hline 12 & 0.375299 & 3.13 & 104.32 \\
\hline 13 & 0.231182 & 1.81 & 112.90 \\
\hline 14 & 0.174262 & 1.33 & 117.81 \\
\hline 15 & 0.065558 & 0.49 & 118.51 \\
\hline 16 & 0.077897 & 0.59 & 119.50 \\
\hline 17 & -0.100825 & -0.76 & 121.19 \\
\hline 18 & -0.045928 & -0.34 & 121.54 \\
\hline 19 & -0.084174 & -0.63 & 122.73 \\
\hline 20 & 0.044715 & 0.33 & 123.07 \\
\hline 21 & 0.047289 & 0.35 & 123.45 \\
\hline 22 & 0.206761 & 1.54 & 130.82 \\
\hline 23 & 0.164715 & 1.21 & 135.53 \\
\hline 24 & 0.315583 & 2.29 & 152.98 \\
\hline 25 & 0.189409 & 1.33 & 159.32 \\
\hline 26 & 0.159249 & 1.10 & 163.84 \\
\hline 27 & -0.025878 & -0.18 & 163.96 \\
\hline 28 & -0.091309 & -0.63 & 165.47 \\
\hline 29 & -0.118905 & -0.81 & 168.06 \\
\hline 30 & -0.092316 & -0.63 & 169.63 \\
\hline 31 & -0.079609 & -0.54 & 170.81 \\
\hline 32 & -0.029110 & -0.20 & 170.97 \\
\hline 33 & 0.125231 & 0.85 & 173.94 \\
\hline 34 & 0.194327 & 1.31 & 181.15 \\
\hline 35 & 0.283334 & 1.89 & 196.64 \\
\hline 36 & 0.205542 & 1.34 & 204.86 \\
\hline
\end{tabular}

Hasil perhitungan PACF pada data in-sample dengan

\begin{tabular}{|c|c|c|}
\hline Lag & PACF & $\mathrm{T}$ \\
\hline 1 & 0.386385 & 4.64 \\
\hline 2 & 0.211207 & 2.53 \\
\hline 3 & -0.186408 & -2.24 \\
\hline 4 & -0.039295 & -0.47 \\
\hline 5 & -0.124225 & -1.49 \\
\hline 6 & -0.012941 & -0.16 \\
\hline 7 & -0.040672 & -0.49 \\
\hline 8 & ๑.077136 & 0.93 \\
\hline 9 & 0.166559 & 2.00 \\
\hline 10 & 0.184813 & 2.22 \\
\hline 11 & 0.199426 & 2.39 \\
\hline 12 & 0.123995 & 1.49 \\
\hline 13 & -0.036096 & -0.43 \\
\hline 14 & ๑. 051505 & 0.62 \\
\hline 15 & 0.055135 & 0.66 \\
\hline 16 & 0.145191 & 1.74 \\
\hline 17 & -0.081561 & -0.98 \\
\hline 18 & ๑.029695 & 0.36 \\
\hline 19 & 0.003120 & 0.04 \\
\hline 20 & 0.015937 & 0.19 \\
\hline 21 & -0.045731 & -0.55 \\
\hline 22 & 0.059140 & 0.71 \\
\hline 23 & $-\odot . \odot \odot 9126$ & -0.11 \\
\hline 24 & 0.165277 & 1.98 \\
\hline 25 & -0.001919 & -0.02 \\
\hline 26 & -0.059569 & -0.71 \\
\hline 27 & -0.139347 & -1.67 \\
\hline 28 & -0.117117 & -1.41 \\
\hline 29 & 0.052091 & 0.63 \\
\hline 30 & $-\odot .0 \odot 8949$ & -0.11 \\
\hline 31 & $-\odot .034793$ & -0.42 \\
\hline 32 & -0.066367 & -0.80 \\
\hline 33 & 0.125058 & 1.50 \\
\hline 34 & 0.026753 & 0.32 \\
\hline 35 & 0.053614 & 0.64 \\
\hline 36 & -0.078955 & -0.95 \\
\hline
\end{tabular}
menggunakan SPSS terlihat pada Tabel 5 dimana disertakan perbandingan dengan T-statistik (t).

Tabel 5. Perhitungan PACF Data in-sample

Nilai-nilai ACF dan PACF selanjutnya digunakan untuk tujuan plotting correlogram.

Gambar 2 menunjukkan correlogram data in-sample, kita mendapatkan dua fakta yaitu nilai ACF membentuk kurva 
sinusoidal yang tidak teredam. Karena $n=144$, kesalahan standar dapat dihitung yaitu sebesar 0,08 dan dikalikan dengan 2,86 (untuk tingkat kepercayaan 5 persen), maka nilai batas kepercayaan untuk ACF dan PACF adalah batas atas berada pada nilai 0,2 dan batas bawah berada pada nilai -0, 2. Nilai ACF (Autocorrelation Function) signifikan secara statistik masih berada diluar tingkat kepercayaan $5 \%$.

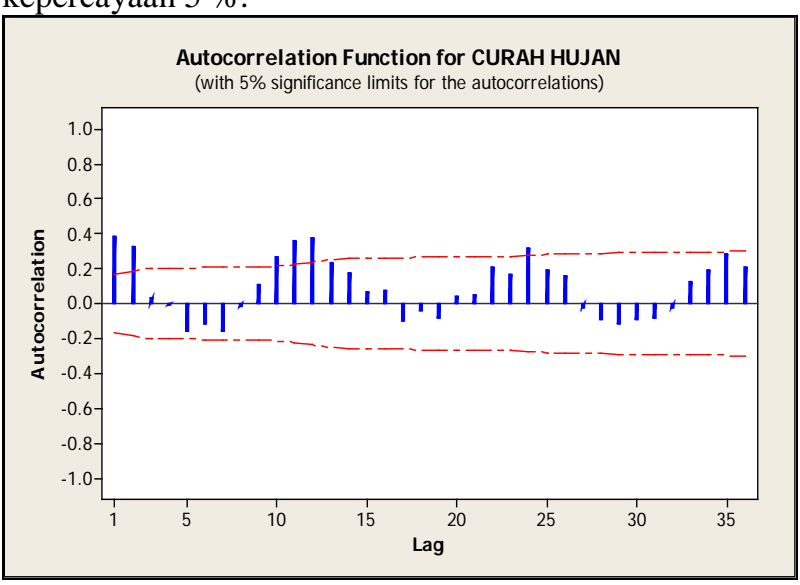

Gambar 2. Correlogram ACF data in-sample

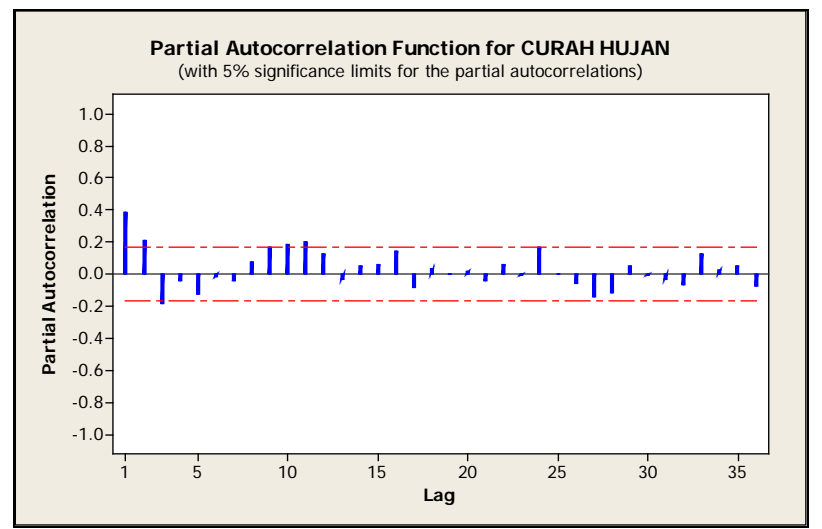

Gambar 3. Correlogram PACF data in-sample

Kedua, setelah lag pertama, nilai PACF(Partial Autocorrelation Function) menurun secara drastis dan seluruh PACF setelah lag 1 tidak signifikan secara statistik dan masih membentuk kurva sinosoidal, terlihat pada gambar 3. Dari kedua fakta diatas menunjukkan bahwa data bersifat non-stasioner. Untuk itu perlu dilakukan pembedaan (differencing) pada data pembentukan model. Dengan melakukan pembedaan ketiga baru didapatkan data yang stasioner. Plot data hasil pembedaan disajikan pada Gambar 4.

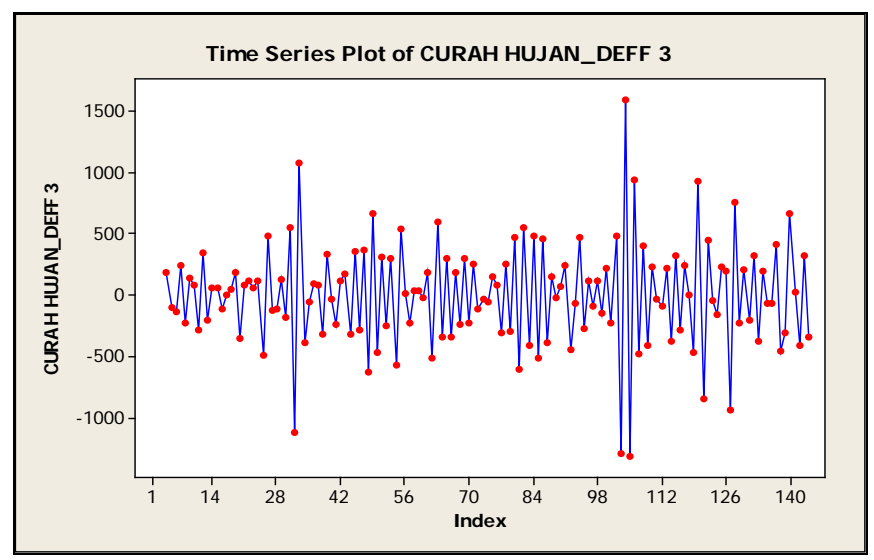

Gambar 4. Plot data pembentukan model (hasil pembedaan ketiga)

Dengan melakukan pengamatan secara visual hasil plot data pembedaan ketiga pada Gambar 4 dapat disimpulkan sementara bahwa pada pembedaan pertama data telah bersifat stasioner. Untuk memperkuat bukti bahwa data telah stasioner maka kita akan melihat correlogram ACF dan correlogram PACF dari hasil pembedaan ketiga.

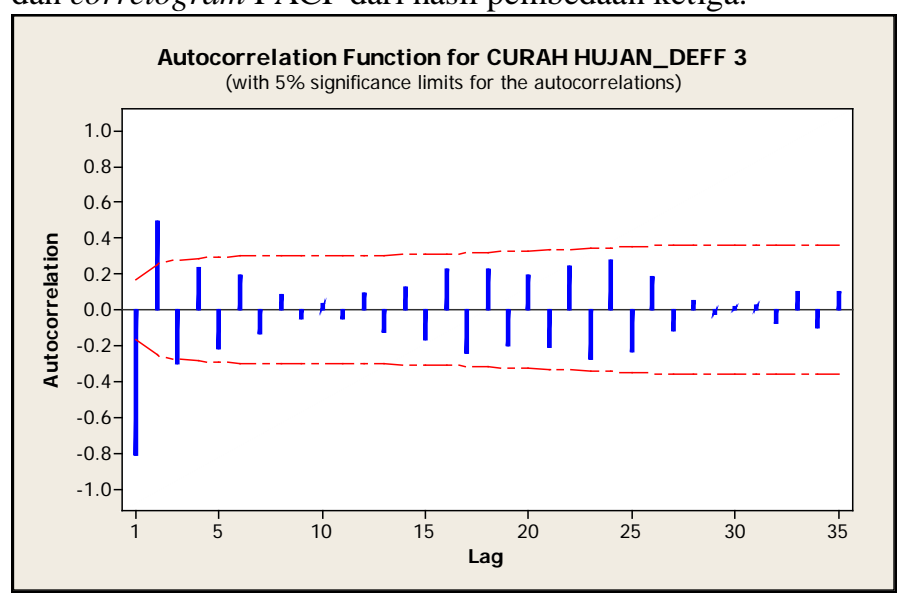

Gambar 5. Correlogram ACF data transformasi pembedaan ketiga.

Dengan mengamati correlogram ACF hasil pembedaan ketiga, terlihat bahwa lag pertama dan kedua nilainya jauh keluar dari garis batas bawah selang kepercayaan (lower confidence limit). Ini mengindentifikasikan sementara bahwa nilai orde q pada MA nilainya 2, tetapi tidak menutup kemungkinan akan dipakai nilai orde yang lainnya.

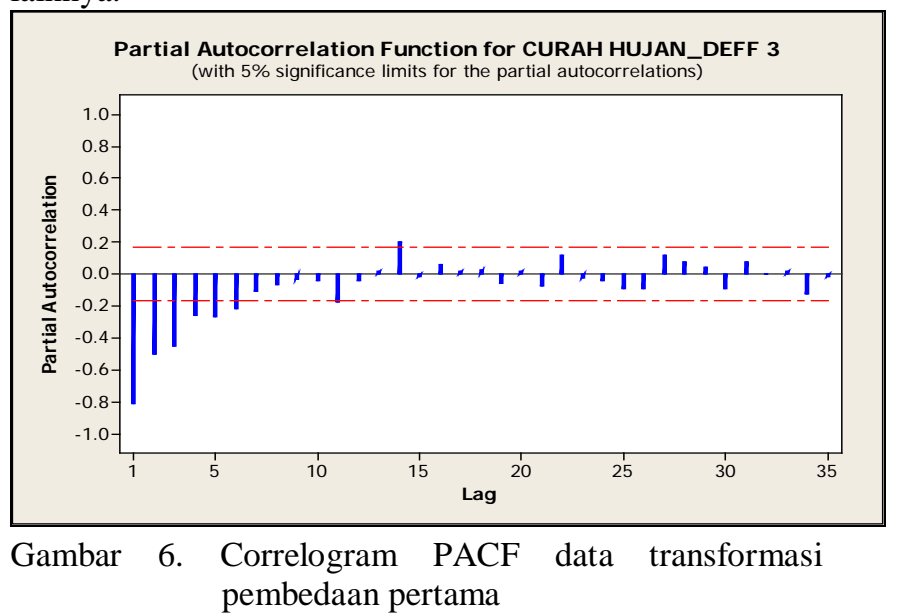


Dari hasil pengamatan corelogram PACF pada Gambar 6, terlihat bahwa pada lag 1 sampai lag 4 nilainya berada diluar garis batas selang kepercayaan. Dapat kita lihat juga correlogram diatas seperti gelombang sinus teredam sehingga ini menunjukkan bahwa pada pembedaan ketiga terlihat data in-sample telah stasioner. Karena pada pembedaan ketiga data telah stasioner, ini mengidentifikasikan bahwa orde d pada model ARIMA bernilai 3.

\section{Identifikasi Model}

Dari pengujian correlogram ACF dan correlogram PACF dari data stasioner yang diperoleh, dapat mengungkapkan apakah terdapat beberapa sifat sebagai berikut:

AR (1) Dimana PACF yang menurun secara eksponensial dan satu ACF yang signifikan.

MA (1) Dimana PACF yang menurun secara eksponensial dan satu ACF yang signifikan.

AR (2) Dimana ACF yang seperti gelombang sinus teredam dan dua ACF yang signifikan.

MA (2) Dimana PACF yang seperti gelombang sinus teredam dan dua ACF yang signifikan.

Perlu diingat bahwa terdapat banyak perwujudan modelmodel sederhana yang dapat kita pakai, tergantung pada nilai dari koefisien AR dan MA. Dari hasil pengamatan correlogram ACF dan correlogram PACF serta didapatkannya orde d dari pembedaan ketiga, maka model yang akan dipakai sementara adalah ARIMA $(2,3,1)$ dan ARIMA (2,3,2). Selanjutnya akan dilakukan estimasi terhadap lag-lag yang ada untuk mendapatkan parameterparameter yang terbaik sehingga sesuai dengan model yang kita pilih. Cara yang dipakai untuk mendapatkan parameter-parameter yaitu dengan melakukan perbaikan secara iteratif (memilih taksiran awal dan kemudian membiarkan program komputer memperhalus penaksiran tersebut secara iteratif).

\section{Estimasi dan Diagnosa}

Mengingat adanya unsur moving average average yang menyebabkan ketidaklinearan parameter maka digunakan metode estimasi non-linear.

Setelah melakukan beberapa iterasi sehingga didapatkan hasil perhitungan yang memperoleh standard error yang kecil. Dari beberapa iterasi yang dilakukan didapat nilai-nilai parameter model yang disajikan pada Tabel 6 .

Tabel 6. Hasil Estimasi Model (Nilai parameter Model ARIMA)

\begin{tabular}{|c|c|c|c|c|}
\hline Variable & Coefficient & Std. Error & T-Statistic & Sig. \\
\hline Constan & $-0,101$ & 1.112 & -0.09 & 0,928 \\
\hline AR (1) & -1.2512 & 0.2551 & -4.90 & 0,000 \\
\hline AR (2) & -0.4698 & 0.1737 & -2.70 & 0,008 \\
\hline MA(1) & 0.5755 & 0.2037 & 2.83 & 0,005 \\
\hline MA(2) & 0.4094 & 0.3317 & 1.23 & 0,219 \\
\hline
\end{tabular}

Pada Lampiran 4 dapat dilihat hasil dari iterasi menggunakan program SPSS, sehingga didapatkan model ARIMA $(2,3,2)$ yang digunakan untuk melakukan peramalan. Uji diagnostik dilakukan dengan menggunakan T-statistik, berdasarkan Tabel 6 nilai tstatistik dibandingkan dengan nilai T-tabel pada derajat kepercayaan 95\% tanpa memperhatikan tanda. Nilai t tabel adalah 1,96 oleh karena itu hanya AR (2) dan MA (2) yang akan digunakan untuk peramalan.

\section{Peramalan}

Data yang digunakan untuk periode peramalan adalah data curah hujan 2003-2009 (Tabel 3). Selanjutnya data yang ada sebanyak 84 disusun secara deret waktu untuk melakukan peramalan.

Statistik data out-sample (Tabel 7) menunjukkan bahwa rata-rata curah hujan selama 84 bulan sebanyak $151 \mathrm{~mm}$, sedangkan nilai tengahnya $109 \mathrm{~mm}$. Nilai tertinggi dari data deret waktu sepanjang 84 bulan adalah $944 \mathrm{~mm}$ orang sedangkan nilai terendah adalah $10 \mathrm{~mm}$. Nilai standar deviasi data, yang menggambarkan sebaran data di sekitar data deret waktu sebesar $52,77 \mathrm{~mm}$.

Tabel 7. Statistik deskriptif data out-sample

\begin{tabular}{|l|c|}
\hline Mean & 151 \\
\hline Median & 109 \\
\hline Maximum & 944 \\
\hline Minimum & 10 \\
\hline Std. Deviasi & 153 \\
\hline
\end{tabular}

Selanjutnya, menerapkan model ARIMA $(2,3,2)$ untuk meramal curah hujan periode berikutnya. Data aktual yang digunakan adalah data curah hujan tahun 2003-2009 (Januari sampai dengan Desember).

Perhitungan peramalan dengan model ARIMA (2,3,2) dilakukan dengan SPSS. Hasil peramalan ARIMA dan data aktual disajikan dalam Tabel 8 . Gambar 7 memperlihatkan pola fluktuasi antara data aktual dan data keluaran ARIMA.

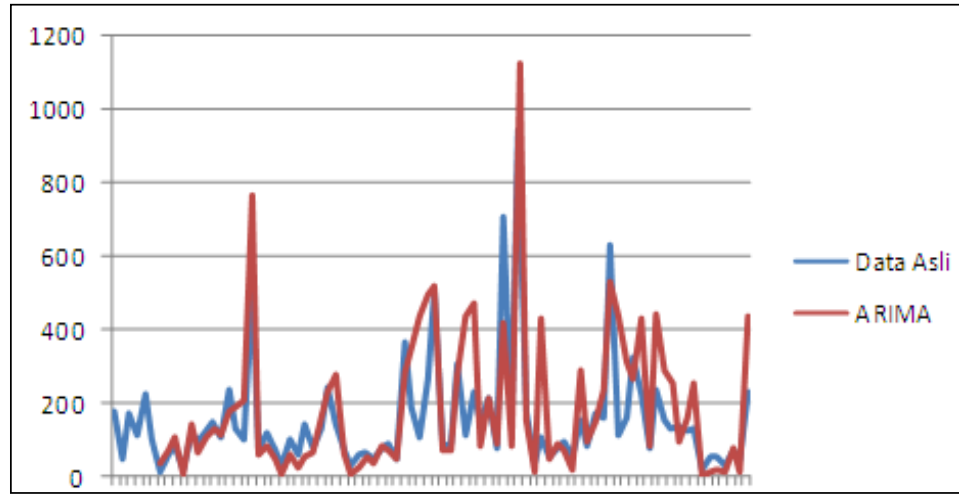

Gambar 7. Grafik Perbandingan Data Hasil Perkiraan Model ARIMAdengan Data Aktual.

Data keluaran peramalan dengan menggunakan ARIMA $(2,3,2)$ akan dimulai pada bulan April 2003, ini disebabkan karena adanya parameter awal yang dipilih dan operasi shift mundur yang digunakan. Sehingga data hasil keluaran ARIMA $(2,3,2)$ hilang pada data awal yaitu pada bulan Januari sampai dengan Maret 2006. Proses peramalan dengan menggunakan program SPSS dilakukan dalam setiap bulan untuk mendapatkan nilai yang signifikan.

Tabel 8. Perbandingan statistik data out-sample dan data hasil ARIMA

\begin{tabular}{|c|c|c|c|c|c|c}
\hline Variabel & N & Mean & MSE & Std.Dev & Max & Min \\
\hline ASLI & 84 & 151 & 16.7 & 153 & 944 & 10 \\
\hline ARIMA & 78 & 191.1 & 22.2 & 196.3 & 1124 & 4 \\
\hline
\end{tabular}

Dengan melihat hasil perbandingan data aktual dan data hasil keluaran ARIMA (2,3,2), baik secara nilai data, 
secara grafik dan perbandingan statistik, terlihat model ARIMA $(2,3,2)$ mempunyai mempunyai pola yang sama dengan data aktualnya. Hal ini menunjukan bahwa model ARIMA $(2,3,2)$ cukup layak untuk memprediksi jumlah curah hujan di Kecamatan Kairatu.

Dengan model ARIMA (2,3,2) pada peramalan menggunakan SPSS maka didapat pada Januari 2010 jumlah curah hujan sebanyak $536 \mathrm{~mm}$, sedangkan pada Februari 2010 di prakirakan jumlah curah hujan sebanyak $495 \mathrm{~mm}$.

\section{KESIMPULAN DAN SARAN}

\section{Kesimpulan}

Dari hasil pengolahan data, analisa data dan pembahasan yang dilakukan, maka dapat ditarik beberapa kesimpulan:

1. Metode ARIMA mempunyai kemampuan peramalan dalam jangka panjang yang cukup memuaskan, sehingga metode ARIMA dapat dijadikan metode evaluasi curah hujan.

2. Model ARIMA $(2,3,2)$ mampu menggambarkan pola fluktuasi curah hujan di Kecamatan Kairatu sepanjang tahun yang hampir sama dengan pola aktualnya. Hal ini berarti model ARIMA $(2,3,2)$ mampu menyerap informasi dari data pengamatan yang ada dengan baik.

3. Model ARIMA $(2,3,2)$ cukup layak dan memadai untuk meramalkan atau memprediksi berapa banyak curah hujan yang akan terjadi pada waktu yang akan datang.

\section{Saran}

1. Perlu adanya pengembangan metode ARIMA lebih lanjut untuk berbagai ragam data deret waktu yang lain agar dapat lebih memahami dan mengetahui penerapan metode ARIMA dalam berbagai bidang.

2. Dalam pengujian model perlu diperhatikan prinsip PARSIMONI (menyatakan bahwa parameter yang dipakai dalam penyesuaian suatu model terhadap data harus sedikit mungkin jumlahnya), atau dengan kata lain dalam pengambilan model harus sesederhana mungkin.

3. Perlu adanya metode tandingan agar dapat membandingkan apakah metode yang lain lebih baik dari metode ARIMA pada kasus yang sama.

\section{DAFTAR PUSTAKA}

Arismunandar. (1988). Teknik dan Metode Peramalan. PT. Ekonisia Fakultas Ekonomi, Jakarta.

H. Imam Ghozali. (2006). Analisis Multivariat Lanjutan Dengan SPSS. Edisi pertama, UNDIP, Semarang.

Iqbal Hasan. (2004). Analisis Data Penelitian Dengan Statistik. PT. Bumi Aksara, Jakarta.

Sugiarto dan Harijono. (2000). Statistik Teori dan Aplikasi. Erlangga, Jakarta.

Surjadi, PA. (1990). Teori kemungkinan dan Statistik. Edisi keempat, ITB, Bandung.

(Soejoenti \& Zanzawi. 1987). Materi Pokok Analisis Runtun Waktu. Karunia, Jakarta.
Spyros Markidakis, Steven C.W \& V.E. McGee. (1999). Peramalan: Metode dan Aplikasi. Terjemahan dari Forecasting, diterjemahkan oleh Untung Sus Andriyanto \& Abdul Basith. Erlangga, Jakarta. 